GENDER STUDIES 20(1)/2021

\title{
sciendo
}

\subsection{8/genst-2022-0008}

\section{THE ROLE OF GENDER IN THE HISTORY OF THE PROFESSIONAL DEVELOPMENT OF SOUTH AFRICAN NURSING AND NURSING ORGANISATIONS}

\author{
JM ESTERHUIZEN \\ D Litt et Phil graduate \\ University of South Africa \\ joanest1@gmail.com \\ GH VAN RENSBURG \\ Professor: Department of Health Studies \\ University of South Africa \\ vrensgh@unisa.ac.za
}

\begin{abstract}
Historically, female nurse leaders endeavoured to make nursing a profession by establishing nursing organisations that could act as agents of change. They were hampered by sociocultural notions of gender: men dominating society, politics, and the economy. Nurses therefore needed positive working relationships with male leaders. In South Africa, such gender dynamics led to the South African Nursing Association (SANA), being influenced by a political system, that is, apartheid, which had dire consequences for the profession. This article illustrates that historically the emerging nursing profession was intimately connected with a changing society: female nurses strove for economic and professional independence but were confined by a male-dominated (medical) society. South African female nurse leaders never openly challenged the political status quo. It is recommended that current South African nursing organisations advocate for gender equality and clarify how they can foster a health-care environment in which gender diversity is the norm.
\end{abstract}

Keywords: gender, sociocultural factors, nurses, nursing organisations, South Africa. 


\section{GENDER STUDIES 20(1)/2021}

\section{Introduction}

Since the days of Florence Nightingale and the religious sisterhoods, nursing has been viewed as a vocation: a calling to take care of those in need, with little consideration of remuneration (Loots \& Vermaak, 1975; Soine, 2010). Historically, the moral character of a nurse was considered more important than her education (Berghs et al., 2006). Vocational groups established professional organisations to help develop their unique identities, which in turn helped group members to increase their value and status as workers (Geyer, 2013). An organised profession increases its authority and political influence so that the group can achieve its stated objectives (Searle, 1982; Searle, 1991). The nature, purpose and type of professional organisation needed by a profession can change over time to ensure that the role of such an organisation remains effective. Transformation in American nurses' organisations, for example, was driven by factors such as changing legislation, social turmoil (e.g., war) and the development of specialised nursing skills for specialised hospitals (Matthews, 2012).

Historically, South African nursing organisations also adapted and transformed. In 1914, the need for a professional nurses' organisation led to the establishment of the South African Trained Nurses' Association (SATNA). Membership was voluntary but restricted to stateregistered nurses only (Harrison, 1982; Searle, 1972). Following the promulgation of the first Nursing Act (no 45 of 1944), nurses favoured a professional association with compulsory membership, namely the South African Nursing Association (SANA) (Harrison, 1982; Searle, 1972; Van Huyssteen 1984). In the 1990s, the Democratic Nursing Organisation of South Africa (DENOSA) was established as a professional association with a trade union section (Democratic Nursing Organisation of South Africa (DENOSA), 2014; Searle \& Pera, 1993; South African Trained Nurses' Association [SATNA], ca. 1942). Today, nurses in South Africa have access to mainstream professional organisations, such as DENOSA and the Health and

Other Services Personnel Trade Union of South Africa (HOSPERSA), and specialist organisations, such as the Forum for Professional Nurse Leaders (FPNL), the South African Theatre Nurse Organisation (SATS), the Neonatal Nursing Association of South Africa (NNASA) and the Nursing Education Association (NEA).

Political, economic and sociocultural factors influenced the development of these South African nursing organisations and, subsequently, the profession. Considering that nurses in the late 19th and early 20th centuries were predominantly female (Sweet, 2007), gender emerged as the most important sociocultural factor that influenced the nursing profession. This article focuses on gender as a sociocultural construct and explains how gender historically influenced 


\section{GENDER STUDIES 20(1)/2021}

the South African nursing organisations' nature and thus the professional development of South African nursing itself.

\section{Methodology and philosophical underpinnings}

A historical inquiry was conducted to explain the factors that influenced the development of South African nursing organisations evident from 1914 to 2014 and to illustrate how these organisations, in turn, influenced the professional development of South African nursing (Esterhuizen \& Van Rensburg, 2021). The discussion in this article is limited to gender as an influencing factor.

Historical inquiry necessitates the researcher to be inquisitive and to conduct a vigorous search for the historical truth (Francis, 2013; Galgano et al., 2008) that is reported in narrative form (Lewenson \& Hermann, 2008). Primary (e.g., archival documents) and secondary (e.g., journal articles) literature sources that explain the history of professional nursing organisations in South Africa were included in the literature search. In that way, the researcher (first author) was the data collection instrument. Repeated and reflective reading, led by questions arising from these critical reflections, and the subsequent analysis of more (newly collected) data enabled the researcher to gain an understanding of historical events. Through this muchrepeated cycle of reflection (Fletcher, 2017), the researcher obtained insights that were recorded in the form of a historical narrative. Critical realism provided the philosophical foundation for the research.

Critical realists accept the world as an open, dynamic system in which each emerging stratum of reality builds on the preceding levels (Burgoyne, 2011). This confirms historians' certainty that the past can influence the present and inform the future. Both critical realism and historical inquiry intend to identify causative mechanisms that effect events. The authors (Esterhuizen \& Van Rensburg, 2021) moved their focus away from the actual historical events that occurred to the causes of these events and how they influenced the professional development of nursing in South Africa.

Historically, South African nursing organisations were vulnerable to political (e.g., apartheid policies), religious (e.g., the Anglican sisterhoods) and sociocultural (perceptions of gender) influences, which, in turn, affected the professional development of nursing. 


\section{GENDER STUDIES 20(1)/2021}

\section{British colonial influence: The role of women in society}

South Africa, being a British colony in the early 20th century, was influenced by international trends and events. Before the outbreak of the First World War (1914-1919), British society was adjusting to the socioeconomic and political changes triggered by the Industrial Revolution. This new socioeconomic climate facilitated the entry of women, traditionally not economically active, into the workplace. Considering that nurses in the late 19th and early 20th centuries were predominantly female, it is reasonable to conclude that the mentioned socioeconomic and political changes affected the nursing profession. An article published in one of the earliest South African Nursing Record editions states that women joined the workforce out of necessity and partly as a matter of choice. According to the author, valuable women workers, such as nurses, emerged (Woman's place..., 1915). Although women became workers, their new socioeconomic status did not include the political right to vote or even participate in political institutions. During Britain's dominion over South Africa (1910-1961), Afrikaner women were, for example, expected to abide by the modest, passive and domestic role portrayed by British ladies (Möller, 2010; Soine, 2010; Spies, 1993; Van der Merwe, 2011).

Male dominance in the early 20th century is accurately portrayed in the 1964 musical "Mary Poppins" (The Internet Movie Database, 2011). The following extract from the musical illustrates this dominance:

Mr Banks: I feel a surge of deep satisfaction, much as a king astride his noble steed thank you. When I return from daily strife, to hearth and wife ... How pleasant is the life I lead!

Mrs Banks: Dear, it's about the children ...

Mr Banks: Yes, yes, yes. I run my home precisely on schedule. At 6:01, I march through my door. My slippers, sherry, and pipe are due at 6:02. Consistent is the life I lead!

Mrs Banks: George, they're missing!

Mr Banks: Splendid, splendid. It's grand to be an Englishman in 1910! King Edward's on the throne, it's the age of men! I'm the lord of my castle, the sovereign, the liege! I treat my subjects, servants, children, wife [sic] with a firm but gentle hand, noblesse oblige. It's 6:03, and the heirs to my dominion are scrubbed and tubbed, and added, quickly fed. And so l'll pat them on the head, and send them off to bed. Ah, lordly is the life I lead! Winifred, where are the children?

Mrs Banks: They're not here, dear.

Mr Banks: What? Well, of course they're here! Where else would they be?

Figure 1: Extract from the 1964 musical "Mary Poppins" (The Internet Movie Database, 2011). 


\section{GENDER STUDIES 20(1)/2021}

Such Victorian notions of family structure, where men were in a position of dominance and women were expected to be subservient (Esterhuizen, 2013), had a significant impact on the hierarchy of healthcare systems, the doctor-nurse relationship and, consequently, the professional status of nurses. Kane and Thomas (2000) confirm that gender roles, educational status and the Industrial Revolution effected change in the healthcare environment. Working class women (nurses) were expected to serve the better educated men (doctors) who were the decision makers (Esterhuizen \& Van Rensburg, 2021). The first edition of the South African Nursing Record explains the status of a nurse as follows: "For her medical man the one lesson a nurse has to learn is obedience - implicit and ungrudging obedience" (Nurse, 1913, p. 21). This power relationship was not restricted to 19th-century hospitals. According to Marks (1994), the dominance of male doctors over female nurses was evident in hospitals as late as the 1940s. In the researcher's experience, it is still evident today but to a lesser extent.

\section{Efforts to create the "female professional" image}

Socio-political inequality disadvantaged women in that they did not have the same access to education as their male counterparts (Soine, 2010). Yet, the Industrial Revolution demanded a new breed of nurses: ones with scientific knowledge and skill. British, European and American nurse leaders realised that to raise nursing to a professional status, they had to address social, political and educational inequality (Esterhuizen \& Van Rensburg, 2021). The early 20th century nurse leaders therefore strove to create the "female professional" image: a woman described by Soine (2010) as having "an ideological mixture of equal rights feminism, socioeconomic and racial superiority, and commitment to educational advancement" (p. 65). Through state registration and college education, nurses gained social respectability and educational status. Yet, in political power structures they still had no influence as women did not have voting rights. Therefore, for nurse leaders to have influence in legislative decision making, women had to become full-fledged citizens: thus, having the right to vote. Support of women's right to citizenship and suffrage would provide (female) nurse leaders access to those (male-dominated) political power structures that would raise nursing from a job that every woman can do to a job that only trained women can do (Helmstadter, 2007; Searle, 1972; Soine, 2010).

Although suffrage for women was a popular cause, nurse leaders at first were hesitant to formally embrace the idea because they feared antagonising their powerful male supporters. 
Levinia Lloyd Dock, also being a member of the International Council of Women, the organisation that advocated for women's vote (suffrage), proposed that the International Council of Nurses (ICN) adopt a resolution to support women's suffrage in 1909, but her proposal was unsuccessful. It was only after a lengthy campaign, during which women's suffrage was tied in with the exploitation of nurses as workers, that the reintroduced resolution was accepted in 1912. By merging the two pursuits, Dock succeeded in gaining the nurses' support for the suffragette cause and the suffragettes' support for the nurses' ambition to achieve professional status: not being workers (sub-servient to the male doctors) only. (Soine, 2010). Years later, Miss Borchards, Chairperson of SANA, would refer to Levinia Dock and state that she worked "for the betterment of conditions for nurses and women generally" (Eleventh Quadrennial Congress, 1958, p. 30).

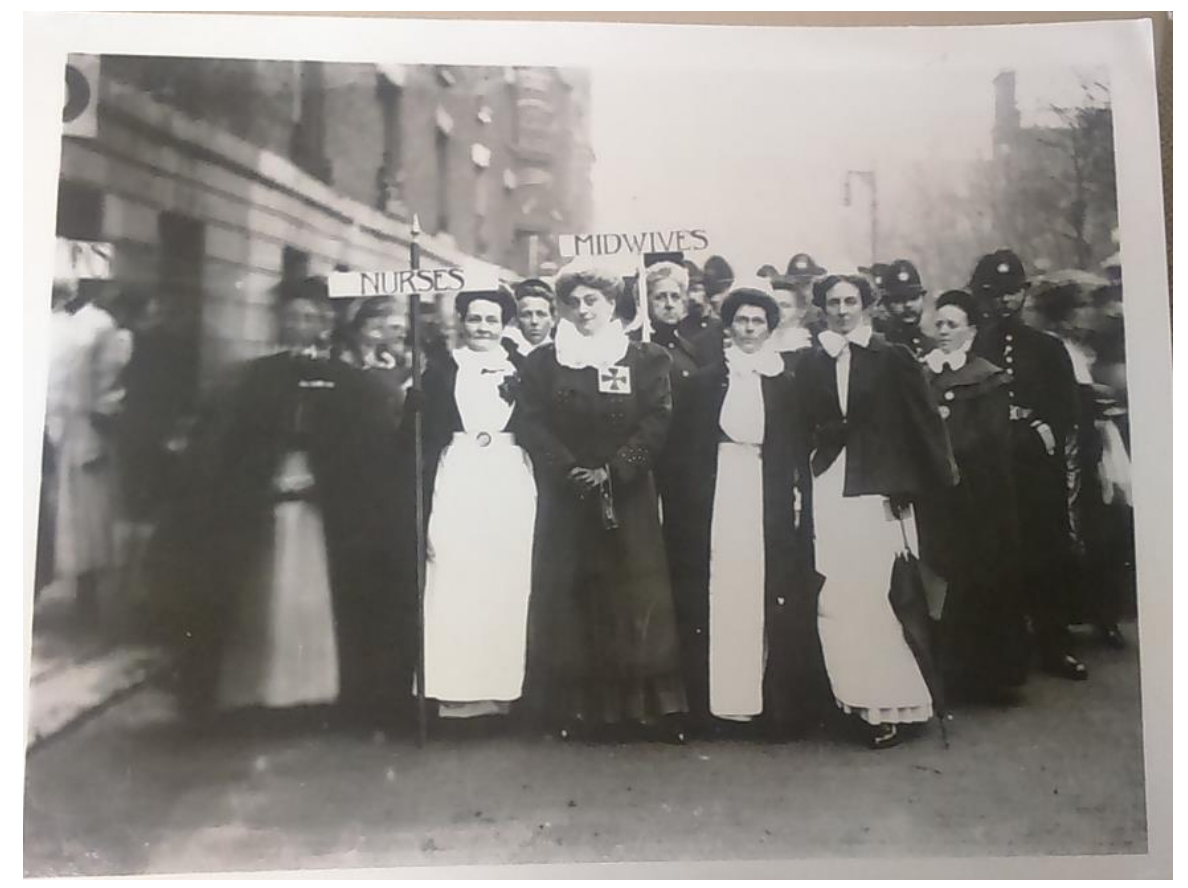

Figure 2: Midwives on a suffragette march in London, 1907 ([Photograph of midwives on suffragette march in London], 1907, Sasol Library Africana Section, University of the Free State).

\section{Female professionals strove to establish professional nursing associations}

In April 1888, the newly established British Nurses' Association (BNA) stated that its primary focus was obtaining state registration for nurses, which would legitimise nurses' claim that they belonged to a profession. Using the 1858 Medical Act (which established a self- 


\section{GENDER STUDIES 20(1)/2021}

governing British Medical Council) as a guideline, the BNA drafted a proposed state registration Act for nurses (Helmstadter, 2007). By 1899, nursing's first international professional organisation, the International Council of Nurses (ICN), was established. The ICN acted as a collective voice in advocating for nurses' rights as women and workers (Lynaugh \& Brush, 1999).

However, some nurses, notably Florence Nightingale, opposed state registration for British nurses. She valued clinical competence and expertise more than social status and prestige. In her opinion, nurses in the 1880s and 1890s were simply not sufficiently educated to claim professional status. In the words of Helmstadter (2007), Nightingale believed that the proposed Nursing Registration Act "would make nursing a legal profession, but a profession without legal rights" (p. 158). Women did not have voting rights and occupied a subservient role in the male dominant society (also note subsections 6-9 of the article). State registration would give control of the profession to medical men and leave nurses as second-class citizens in their own organisations (Helmstadter, 2007; Soine, 2010). Mrs Ethel Bedford Fenwick, founding member of the BNA and the ICN, came to the same conclusion. In an 1887 speech, she referred to the inclusion of physicians in the BNA's governing structure and argued that "the medical profession may always have a controlling voice in the management of the Association" (Soine, 2010, p 62). It was a conundrum: to legitimise their claims of being a profession, the female nurse leaders of the early 20th century needed male (medical) support, but they also recognised that those supporters might very well hamper their pursuit of sociopolitical equality (Esterhuizen \& Van Rensburg, 2021). Women's strategy of positioning themselves within the patriarchal system (not alienating powerful men but rather constructing a benevolent, work relationship) to obtain support for their endeavours would be evident until the 1940s (Marks, 1994).

In South Africa, this strategy was also evident. Searle (1972) states that it was the involvement of prominent British doctors in the BNA that persuaded doctors in the Cape Colony to give Sister Henrietta Stockdale's proposed state registration of nurses and midwives due consideration. In Kimberley, where she worked as a nurse, midwife and administrator, she was in close communication with prominent medical and political men who assisted her with the nurses' drive for state registration. She visited Cape Town and had interviews with politicians such as the Chairman of the Select Committee on Medical Reform, Dr WG Atherstone, requesting him to support the inclusion of registered nurses and midwives in the then proposed medical bill (Buss \& Buss, 1976; Marks, 1994; Searle, 1975). She also wrote letters to prominent medical doctors, and her Kimberley hospital report was presented to Parliament 
(Marks, 1994; Searle, 1972). The culmination of her efforts was that trained South African nurses in the then Cape Colony were granted voluntary state registration in 1891 - the first nurses in the world to be awarded such status (Searle, 1991). State-registered nurses were placed under the control of the (male-dominant) Medical Council.

Sister Henrietta expressed concern about the absence of a South African nurses' association, but ill-health prevented her from taking the lead in establishing such a professional organisation. She died in 1911, before the first independent South African professional nurses' association, SATNA, was established on 1 October 1914. By then, Dr Thorton, the Medical Inspector of Hospitals and Charitable Institutions in the Cape Province, warned that nurses would need their own governing body because they were not represented in the (then provincial) Medical Councils (Buss \& Buss, 1976; Marks, 1994; Report Medical Inspector, 1914). Nurses' own governing body, the South African Nursing Council (SANC), would only be established in 1944.

\section{Female nurses' working relationships with male leaders}

The late 19th-century lady nurse held a leadership role within the hospital, yet such powers were dependent on the goodwill of the medical (male) doctors. Sister Henrietta Stockdale, being aware of the patriarchal society in which she functioned and adhering to the professional etiquette taught by Florence Nightingale, carved out an independent (be it limited) role for herself. She did so by creating working relationships with the medical, political and religious leaders of the day (Berghs et al., 2006; Marks, 1994; Searle, 1985). Dr Callender and Dr Hirst Watkins (brother of Sister Mary, the first registered midwife in South Africa) assisted with the campaign for the 1891 state registration of nurses (Searle, 1965). Cecil John Rhodes and Dr Leander Starr Jameson (synonymous with the Jameson Raid of 1895-1896) served on the Kimberley Hospital Board where Sister Henrietta was the first Sister-in-Charge. In her South African War (1899-1902) diary, Sister Henrietta mentioned that Rhodes regularly provided the sisters with fruit and vegetables during the siege of Kimberley (Buss \& Buss, 1976).

Other South African nurse leaders would follow Sister Henrietta's example to network with the male leaders of the day. In 1934, the eminent Dr AB Xuma, practising in Doornfontein, Johannesburg, was invited to become an honorary member of the Bantu Trained Nurses' Association (BTNA). Dr Xuma became the President of the ANC in 1940 (South African History Online, 2016). He attended the second annual BTNA meeting, which was held on 9 


\section{GENDER STUDIES 20(1)/2021}

December 1934. Also attending that meeting was Mr JD Rheinallt Jones, the then advisor to the South African Institute of Race Relations (SAIRR) (Bantu Trained Nurses' Association [BTNA], 1934).

\section{The changing role of women (nurses) in society created tension}

Early 20th-century women's traditional home-based role was transformed due to the influences of the South African War (1899-1902), industrialisation, urbanisation and the Great (economic) Depression. In an emerging, more liberal socioeconomic society men unexpectedly had to compete with women in the labour market (Marks, 1994), while female workers strove to have their voices heard. The resultant tension was effectively illustrated in communication between SATNA and the Medical Council. The leading article, titled "The Trained Nurses' Association and the Medical Councils", of the January 1918 edition of the South African Medical Record was published in reaction to SATNA's comments about the Medical Councils' management of military probationers and Coloured nurses. After a two-and-a-half-page rebuttal, the Medical Council concluded that although doctors were thankful for the assistance of trained nurses and had sympathy for their striving to become an independent profession: "it will be most regrettable if this leads to an ignoring of the essential fact that the nurse ought always to be a sub-ordinate assistant of the medical practitioner" (Trained Nurses..., 1918, p. 3). Evidently, women nurses were aware of (and struggling against) the subservient role they were awarded and their dependence on the support and approval of the male doctors (Marks, 1994; Third Annual Meeting ..., 1918).

The view that women were professional persons and workers echoed Lavinia Dock's 1913 speech to the American Nurses' Association (ANA). On 26 June 1913, she called on nurses to consider issues not only of professionalism but also of education and remuneration since she felt that nurses as a workforce were being exploited (Soine, 2010). The Industrial Revolution necessitated the creation of specialised labour: persons with training and certification. Training had to be provided by professional training schools, with certification managed by a professional organisation, thus establishing an elite group with its own expertise and ethics (Searle, 1987). Dr John Tremble, the British physician who played a key role in establishing SATNA, advocated that nurses should constantly adapt their practice to accommodate changes in societal thought and contexts. In response to the statement that nursing was not what it used to be, he replied: "Why should it be the same? Society is not what it used to be" (Searle, 1975, p. 14). In fact, he expected nurses to anticipate change and to act in a way 


\section{GENDER STUDIES 20(1)/2021}

that would establish professional and ethical standards of which future South African nurses would be proud (Traditions, 1915). Nurses opted to illustrate their professional status as trained nurses by wearing a distinctive nurses' uniform (Uniform The, 1915). Radloff (1970) explains that SATNA had several challenges to overcome: these women battled "prejudice against the role a women's group was playing” (p. 32).

\section{The (male) Medical Council in control}

Although South African nurses had two representatives on the unified Medical Council from 1928 onwards, the medical fraternity still controlled nurses' professional affairs (e.g., disciplinary action, examinations and registration). The two nursing representatives could vote on nursing matters only (Kotzé, 2013). Such constraints irked the liberal-minded female SATNA leaders, who complained of being treated as minors. This provided the impetus to campaign for an increased representation on the Medical Council's Nursing Committee or, alternatively, an own regulatory body in the form of a nursing council (SATNA, 1938; Third Annual..., 1918). SATNA's 1938 and 1943 efforts in this regard were, however, unsuccessful. The Secretary for Public Health, wishing to avoid a "protectionist" nursing council (as had happened in Britain) and citing unrealistic requirements of nursing candidates (which exacerbated the existing nursing shortage), opposed the idea of nurses having a greater say in nursing matters. Not even support expressed by SATNA members in a referendum could sway his opinion (Marks, 1994; Radloff ,1970).

Not all medical doctors were reluctant to welcome nurses to the fold. At their first attendance of a Medical Council meeting (22 October 1928), the two nurse representatives were welcomed by Dr DF Malan, the then Minister of Interior, Education and Public Health. He confirmed that it took the male members of society long to realise that it was predominantly women who took care of the society's sick - and that they should therefore have a say in the formulation of public health policy (Searle, 1965). Other influential medical men such as Dr Ronald Mackenzie, Superintendent of Johannesburg General Hospital and member of the Transvaal Medical Council, supported nurses in their endeavours (Searle, 1965). University of the Witwatersrand professors Raymond Dart and Philip Tobias advocated for sister tutor training at university level (Horwitz, 2011). The ardent nurse champion, Dr John Tremble, referred to the "trinity of medicine, nursing and pharmacology" and emphasised that the three professions acted interdependently. He did, however, view the doctor as the leader in the healthcare environment, there to guide the other two professions to maturity. His ideal for South 
African nursing was expressed in the February 1915 edition of the South African Nursing Record (Traditions, 1915, p. 107) as follows:

\begin{abstract}
You young nurses in this young and promising country of ours, we wonder if you know how fortunate you are. For your traditions are still to build, and it is for you to build them ... what an opportunity you have got, not merely to follow in others' footsteps, but to give the lead and set the pace ... do not be content to be merely ordinary, be more than that.
\end{abstract}

\title{
9. Social decorum and political influence. Consequences for the profession in the 1960s -1990s
}

The Nursing Act (no 69 of 1957) prescribed that the SANA Board should be controlled by white nurses and that the branches of SANA should be racially segregated. If the Nursing Act (no 69 of 1957) was not complied with, the Minister had the power to rectify SANA Board elections, nominations and appointments (Comparison between..., 1957; Points in Nursing Bill, 1957).

The historical inquiry did not produce any proof that the SANA Board secretly supported the government's segregationist policies; nor is there proof of active, open defiance (Esterhuizen, 2019). Rather, the Board engaged in a course of quiet diplomacy. SANA complied with government legislation yet continued to engage with their now segregated branches and with the nursing associations of neighbouring states (the so-called homelands) (SANA, 1982; SANA, 1983). While South African nurses had the government's support in 1942 when trade unionism was a common threat, the 1959 apartheid politicians did not tolerate opposition to their doctrine. Considering the Minister's veto power, open resistance would have cost the female led professional organisation dearly (Esterhuizen \& Van Rensburg, 2021). Ultimately, SANA's compliance with the statutory laws of apartheid was interpreted as support of those laws. Increased criticism and pressure from the international nursing community would result in SANA withdrawing as member of the ICN in 1973. Nationally, SANA's efforts to maintain a professionally neutral stance splintered the nursing profession along racial lines and politicised South African nurses.

Specific political, economic and ethical factors motivated SANA's decision to leave the ICN in 1973 (Esterhuizen \& Van Rensburg, 2021). Only the South African parliament could modify the offensive Nursing Act (69 of 1957); the association had little political influence. The cost of developing the newly segregated SANA branches and the increased cost of ICN 
membership created a financial strain. Furthermore, the SANA leaders found the suggestion that nurses should participate in strike action to oppose their government ethically unacceptable (SANA, 1973). While South African nurses would have been completely isolated in 1959, the situation changed by 1973 so that their withdrawal from the ICN did not spell total ruin. Internally, SANA created specialist discussion groups and connected with other international health organisations (Harrison, 1982; Radloff, 1970; SANA, 1964). Their members therefore still had access to professional development opportunities and research.

In the country's district nursing services, the shortage of doctors and the rapidly expanding population required the role of South African nurses to expand, that is, nurses had to assume tasks that had previously been those of physicians (e.g., postoperative surgical care, midwifery and the tasks of research assistants). In the 1960s, nurses redefined themselves as co-therapists with medical practitioners, that is to say, as their professional partners (Radloff, 1970). In the future, nurses' training had to include science and technology, which implied tertiary education and research activities. This, in turn, meant that trained nurses should reap an economic reward in the form of an applicable salary and that only trained persons should use the title "nurse" (Radloff, 1970; SANA, 1960).

Radloff (1970) gives a detailed description of SANA's influence on the economic welfare of nurses. The Association made numerous representations to government structures, such as the Minister of Health, the Department of Health, provincial administrations and hospitals, about increased salaries and leave privileges for nurses (e.g., the concepts of study leave and maternity leave were established). She acknowledges that, at times, the negotiations were successful, while sometimes less so. In 1966, for example, great strides were made with the salaries of white nurses but not with those of black nurses. SANA therefore conducted an economic survey to provide its negotiators with information that could inform future salary negotiations.

Although women and nurses gradually gained economic, political and professional independence in the 20th century, they remained a marginalised, subservient group in South Africa in the period from the 1960s to the 1990s (Gourley, 1995; Möller, 2010). African nurses, in particular, occupied a dual social status. They were marginalised by the greater South African society as being black women, yet in the healthcare environment they were regarded as elite, educated nurses. Black nurses were socialised to follow professional nursing's non-political ideals. Most nurses did not to speak out about the inequalities evident in the healthcare system because the rules of the profession (as laid down by SANC and professed by SANA) and the subservient role of women in society discouraged it (Buch, 1990; Kedijang \& Buch, 1990:55; 


\section{GENDER STUDIES 20(1)/2021}

Rispel \& Schneider, 1990). They therefore did not question their place in the then authoritarian society, but rather worked within it. Some white women protested the political system, while others tried to assist those who were oppressed (Möller, 2010; Uys, 1987). "Although the Association [SANA] has repeatedly taken a stand against issues such as the fragmentation of health services and the racial discrimination against some of its members, perhaps these protests were put in such a submissive way that they were not even heard" (Uys, 1990, p. 76).

\section{Conclusion}

In the 19th and early 20th centuries, nursing started as a vocation, the focus being on the provision of selfless care to those in need; remuneration was not prioritised. Early female nurse leaders endeavoured to change the nature of nursing from a vocation to a profession. To achieve this goal, they chose to establish nursing organisations that would act as the agents (vehicles) that could bring about the required change.

However, sociocultural (Victorian/British) notions of gender hampered their progress. It was an era where men occupied the dominant, leading roles in society, politics and the economy. Societal changes due to war and the Industrial Revolution brought women into the workplace; yet the lesser trained female nurses remained dependent on the goodwill and support of the better educated male leaders. Nurse leaders were faced with a dilemma: to establish an independent (then female-dominant) profession, they had to develop positive working relationships with society's (then male-dominant) leadership. In South Africa, such gender dynamics led to the only recognised professional organisation for nurses, SANA, being influenced by the political system of the day, that is, apartheid, which had dire consequences for the profession.

South African nursing organisations enabled nurses to move from being subservient female assistants in the 1920s to being doctors' partners in the 1960s. Trained nurses gained professional status and reaped the economic rewards. Yet, as females they remained socially and politically marginalised, seldom challenging their assigned position. Referring to the development of the nursing profession, Searle (1987) argues: "Being manifestations of social evolution and organisation, all issues have an ongoing evolutionary thrust and are bedevilled by the constraints of the era" (p. 116).

This article illustrates that historically the emerging nursing profession was intimately connected with a changing society: female nurses strove for economic and professional independence but were confined by a male-dominated (medical) society. While they toiled to 


\section{GENDER STUDIES 20(1)/2021}

establish independent, professional nursing organisations, South African female nurse leaders never challenged the political status quo.

In the past one hundred years, the struggle for gender equality in South African nursing was predominantly one of traditionally subservient females finding their voices in a male dominated society. However, in modern society gender is redefined as being more than merely male or female. It is recommended that current South African nursing organisations and nurse leaders encourage and enable all nurses to participate in their profession's organisational activities. This can be achieved by advocating for gender diversity and creating a mentorship programme aimed at supporting young nurses irrespective of gender when they assume nurse leadership roles in their places of work and/or in the structures of professional organisations. Furthermore, in their training, student nurses should be given opportunities to discover how notions of gender have historically influenced the nature of their profession. They should also clarify for themselves how they, as future nurse leaders, can foster a healthcare environment in which gender diversity is the norm.

\section{Acknowledgments}

The authors are grateful to the Sasol Library, University of the Free State, South Africa, for permitting them to use the archival photograph from the Henrietta Stockdale Collection reproduced in Figure 2. This article draws upon the doctoral thesis (D Litt et Phil - Health Studies) completed by Dr. J. M. Esterhuizen under Professor G. H. van Rensburg's supervision: The influence of nursing organisations on the development of the nursing profession in South Africa: 1914-2014, (University of South Africa, 2019).

\section{References}

Bantu Trained Nurses' Association. (1934). BTNA Dr Xuma papers 1930s. Records of the South African Institute of Race Relations, File no. AD843-B1-009, Doc no ABX 341003 and ABX 341209, Department of Historical Papers, University of the Witwatersrand, Johannesburg, Gauteng province, South Africa.

Berghs, M., Dierckx de Casterlé, B. \& Gastmans, C. (2006). Nursing, obedience, and complicity with eugenics: a contextual interpretation of nursing morality at the turn of the twentieth century. Journal of Medical Ethics, 32(2), 117.

Buch, E. (1990). Foreword. In L.C. Rispel (Ed.), Nursing at the crossroads: organisation, professionalisation and politicisation (pp. i). University of the Witwatersrand.

Burgoyne, J. (2011). Critical realism. In R. Thorpe \& R. Holt (Eds.), The SAGE Dictionary of Qualitative Management Research (pp. 1-4). SAGE.

Buss, W. M. \& Buss, V. (1976). The lure of the stone: the story of Henrietta Stockdale. Howard Timmins. 


\section{GENDER STUDIES 20(1)/2021}

Comparison between the 1944 and 1957 Nursing Acts, indicating the major changes which have taken place. (1957). South African Nursing Journal, XXIV(8), 10-14.

Democratic Nursing Organisation of South Africa. (2014). About us. Retrieved from http://www.denosa.org.za/About.php?id=339 [Accessed 2014, August 3].

Eleventh Quadrennial Congress of the International Council of Nurses, Rome, June 1957. (1958). South African Nursing Journal, XXV(8), 30-36.

Esterhuizen, J. M. (2013). The professional development of black South African nurses 1908-1994: a historical perspective [Master's dissertation, University of South Africa]. University of South Africa, Institutional repository. Retrieved from http://uir.unisa.ac.za/handle/10500/13178 [Accessed 2014, November 9].

Esterhuizen, J. M. (2019). The influence of nursing organisations on the development of the nursing profession in South Africa: 1914-2014. [Doctoral thesis, University of South Africa]. University of South Africa, Institutional repository. Retrieved from http://uir.unisa.ac.za/handle/10500/26157 [Accessed 2020, May $5]$.

Esterhuizen, J. M. \& Van Rensburg, G. H. (2021). The influence of nursing organisations on the development of the nursing profession in South Africa. International Journal of Africa Nursing Science, 14, 100290. Retrieved from https://doi.org/10.1016/j.ijans.2021.100290 [Accessed 2021, February 1].

Fletcher, A. (2017). Applying critical realism in qualitative research: methodology meets method. International Journal of Social Research Methodology, 20(2), 181-194.

Francis, K. (2013). Historical research. In B. Taylor \& K. Francis (Eds.), Qualitative research in the health sciences: methodologies, methods and processes (pp.57-64). Routledge.

Galgano, M. J., Arndt, J. C., \& Hyser, R. M. (2008). Doing history, research and writing in the digital age. Thomson Wadsworth.

Geyer, N. (2013). Organisation of nurses and midwives. In N. Geyer (Ed.), A new approach to professional practice (pp. 194-206). Juta.

Gourley, B. M. (1995). The place of nurses in our society today. Curationis, 18(1), 2-4.

Harrison, P. (1982). Reorganisation of the South African Nursing Association and the implications thereof. Curationis, 5(1), 4-6.

Helmstadter, C. (2007). Florence Nightingale's opposition to state registration of nurses. Nursing History Review, $15,155-166$.

Horwitz, S. (2011). The nurse in the university: a history of university education for South African nurses: a case study of the University of the Witwatersrand. Nursing Research and Practice, 2011, 1-9.

Kane, D. \& Thomas, B. (2000). Nursing and the "F" word. Nursing Forum, 35(2), 17-24.

Kedijang, M., \& Buch, E. (1990). Some aspects of the political economy of health in South Africa: perceptions of nurses in the Witwatersrand area. In L.C. Rispel (Ed.), Nursing at the crossroads: organisation, professionalisation and politicisation (pp. 55-61). University of the Witwatersrand.

Kotzé, W. J. (2013). The development of statutory control of nursing and midwifery in South Africa. In N. Geyer (Ed.), A new approach to professional practice (pp. 59-78). Juta.

Lewenson, S. B., \& Hermann, E.K. (2008). Capturing nursing history. Springer.

Loots, I., \& Vermaak, M. (1975). Pioneers of professional nursing in South Africa. PJ de Villiers.

Lynaugh, J. E. \& Brush, B. L. (1999). The ICN story: 1899-1999. International Nursing Review, 46(1), 3-8. 


\section{GENDER STUDIES 20(1)/2021}

Marks, S. (1994). Divided sisterhood. MacMillan.

Matthews, J. H. (2012). Role of professional organisations in advocating for the nursing profession. Online Journal Issues Nursing, 17(1), 1-13.

Möller, P. L. (2010). They also served: ordinary South African women in an extraordinary struggle: the case of Erna de Villiers (Buber). New Contree, 59, 61-84.

Nurse, The. (1913). South African Nursing Record, I(1), 19-21.

[Photograph of midwives on suffragette march in London]. (1907). Dokumente van Prof. C. Searle (Karton 17:

No 12.1, Foto's: laat 19de en vroeë 20ste eeu), Henrietta Stockdale collection, Sasol Library Africana Section, University of the Free State, Bloemfontein, Free State province, South Africa.

Points in the Nursing Bill. (1957). South African Nursing Journal, XXIV(7), 4.

Radloff, D. H. (1970). Socio-economic progress for nurses in South Africa through professional organisation 19141969. South African Nursing Organisation.

Report of the Medical Inspector of Hospitals for the Cape. (1914). South African Nursing Record, I(9), 314-315.

Rispel, L., \& Schneider, H. (1990). Professionalisation of South African nursing: who benefits? In L.C. Rispel

(Ed.), Nursing at the crossroads: organisation, professionalisation, politicisation (pp. 20-54). University of the Witwatersrand.

SANA - see South African Nursing Association

SATNA - see South African Trained Nurses’ Association

Searle, C. (1965). The history of the development of nursing in South Africa 1652-1960. Struik.

Searle, C. (1972). Die Geskiedenis van die ontwikkeling van verpleging in Suid-Afrika 1652-1960. Suid-Afrikaanse Verpleegstersvereniging.

Searle, C. (1975). Some aspects of nursing education. In SANA (Ed.), South African Nursing Association Contemporary Series No 1 (pp. 11-16). South African Nursing Association.

Searle, C. (1982). The evolution of a profession. Curationis, 5(3), 4-7.

Searle, C. (1985). Nursing is the concern of all citizens*. Curationis, 8(2), 4-8.

Searle, C. (1987). Ethos of nursing and midwifery. Butterworths.

Searle, C. (1991). Towards excellence: the centenary of state registration for nurses and midwives in South Africa 1891-1991. Butterworths.

Searle, C., \& Pera, S. (1993). Professionele praktyk, 'n Suid-Afrikaanse Verpleegperspektief(2nd ed.). Butterworths.

Soine, A. (2010). The relation of the nurse to the working world: professionalization, citizenship, and class in Germany, Great Britain, and the United States before World War I. Nursing History Review, 18, 51-80.

South African History Online. (2016, November 13). Dr Alfred Xuma. Retrieved from

http://www.sahistory.org.za/people/dr-alfred-xuma [Accessed 2016, November 13].

South African Nursing Association. (1960). Report of the Board of the South African Nursing Association, September 1958 to October 1960. Folder C1/12 volume 2, Democratic Nursing Organisation of South Africa archives, Pretoria, Gauteng province, South Africa.

South African Nursing Association. (1964). Report of the Board of the Association for period November 1962 to October 1964, submitted to the Golden Jubilee Congresses held in 1964. SANA Board Reports 1960- 


\section{GENDER STUDIES 20(1)/2021}

1975 no 2, Democratic Nursing Organisation of South Africa archives, Pretoria, Gauteng province, South Africa.

South African Nursing Association. (1973). SANA matters dealt with in committee at the Board meeting held in Pretoria on 20 and 21 July 1973. Karton 5: Dokumente van Prof. C. Searle No 2, Betrokkenheid by Organisasies, Henrietta Stockdale collection, Sasol Library Africana Section, University of the Free State, Bloemfontein, Free State province, South Africa.

South African Nursing Association. (1982). SANA minutes: discussion on formation of (LONASA) The League of Nursing Associations of Southern Africa. ExCoR/UitKo V 4-4/82, SANA Board Meetings 1982, Democratic Nursing Organisation of South Africa archives, Pretoria, Gauteng province, South Africa.

South African Nursing Association. (1983). Verslag van die President van die Suid-Afrikaanse Verpleegstersvereniging, Prof. MC van Huyssteen, ten opsigte van die werksaamhede van die Sentrale Bestuur en die streke van die Vereniging gedurende 1982. E22-1/83, SANA Executive Committee Meetings 1983, Democratic Nursing Organisation of South Africa archives, Pretoria, Gauteng province, South Africa.

South African Trained Nurses' Association. (1938). Report of Finance sub-committee to Executive committee. Democratic Nursing Organisation of South Africa archives, File no C1-6(a), Pretoria, Gauteng province, South Africa.

South African Trained Nurses' Association. (ca. 1942). The South African Nurses' Union (application form). SATNA Witwatersrand Branch: Minute Book and General Meetings July 1940-May 1945, File B2-16 volume 1, Democratic Nursing Organisation of South Africa archives, Pretoria, Gauteng province, South Africa.

Spies, S. B. (1993). Part I: 1900-1919. In B.J. Liebenberg \& S.B. Spies (Eds.), South Africa in the 20th century (pp. 3-137). Van Schaik.

Sweet, H. (2007). Establishing connections, restoring relationships: exploring the historiography of nursing in Britain. Gender and History, 19(3), 565.

The Internet Movie Database. (2011, May 15).Mary Poppins(1964): quotes. Retrieved from http://www.imdb.com/title/tt0058331/quotes [Accessed 2011, May 15].

Third Annual Meeting of the Central Board of the T.N.A. (1918). South African Nursing Record, V(7), 147-152.

Traditions. (1915). South African Nursing Record, II(17), 107-108.

Trained Nurses' Association and the Medical Councils. (1918). South African Medical Record, 16(1), 1-3.

Uniform, The. (1915). South African Nursing Record, II(20), 187.

Uys, L. (1990). The future of nursing organisations in South Africa. In L.C. Rispel (Ed.), Nursing at the crossroads: organisation, professionalisation, politicisation (pp. 71-79). University of the Witwatersrand.

Uys, L. R. (1987). Racism and the South African nurse. Nursing RSA Verpleging, 2(11/12), 55-56.

Van der Merwe, R. (2011). Moulding volksmoeders or volks enemies? Female students at the University of Pretoria, 1920-1970. Historia, 56(1), 77-100.

Van Huyssteen, M. C. (1984). The South African Association - Quo Vadis. Curationis, 7(3), 4-10.

Woman's place in nature. (1915). South African Nursing Record, III(27), 63-65. 
Joan ESTERHUIZEN obtained her doctorate degree from the University of South Africa. She conducts historical inquiries into the history of South African nursing. Two scientific articles were published in international journals from historical research conducted as part of postgraduate studies. Several articles on history and the influence of history on the profession and teaching have been published in professional newsletters and in-house journals. She is the founder of the South African Nursing History Forum, an online platform with South African nursing history as focus. She is a South African nursing educator at a Private Higher Education Institution where she teaches Professional Practice of Nursing, Nursing Science and clinical nursing skills to undergraduate nursing students. Her knowledge on history has enriched the teaching of professional practice to students. Joan has presented oral and poster presentations at both national and international conferences.

Gisela VAN RENSBURG is a Professor in the Department of Health Studies at the University of South Africa where she teaches research methodology and health sciences education. She has a special interest in research capacity development and reflective practice, which is also extended to community engagement activities that include developing novice researchers in the healthcare environment. Her research focus lies in student support in an Open Distance and eLearning context and reflective practice. She also supervises Masters and Doctoral candidates in this field of study. Gisela has published scientific articles in both national and international journals and has presented oral and poster presentations, and seminars at various conferences, nationally and internationally. 